\title{
Pollination as a factor limiting the yield of field beans (Vicia faba L.)
}

\author{
By J. B. FREE AND INGRID H. WILLIAMS \\ Rothamsted Experimental Station, Harpenden, Hertfordshire
}

(Received 29 January 1976)

\begin{abstract}
SUMMARY
Self-pollinating and cross-pollinating by hand samples of flowers in field bean crops usually gave an increased set of seed compared with control flowers left to be pollinated naturally. Hence, insect pollination of field bean crops is often inadequate. In large fields of more than 12 ha the seed yield was greater by plants near the edge than near the centre. Fewer pods were produced from nodes at the upper than the lower parts of a stem, and they contained fewer seeds which were of a smaller size.
\end{abstract}

\section{INTRODUCTION}

A commercial crop of field beans consists of about one-third hybrid plants and two-thirds inbred plants (e.g. Sirks, 1923; Hua, 1943; Fyfe \& Bailey, 1951 ; Fyfe, 1954; Rowlands, 1958). The flowers of hybrid plants are able to set seed from autopollination and their progeny is produced predominantly by self-fertilization. However, flowers of inbred plants have some mechanical barrier to autopollination that is absent in hybrid flowers and although self-fertile do not set seed unless visited by insects. As a result of this about half their progeny are from cross-fertilization (Drayner, 1959).

It might be expected, therefore, that although the autofertility of the hybrid plants would ensure a fair crop under conditions of poor pollination, insect pollination could improve the yield by pollinating the inbred plants. Furthermore, seed produced under conditions of poor pollination would produce a crop still more in need of insect pollination.

Experiments in which plots of field beans have been caged to exclude or contain pollinating insects have demonstrated that insect pollination increases yield by about a third (e.g. Riedel \& Wort, 1960; Scriven, Cooper \& Allen, 1961; Watts \& Marshall, 1961 ; Cooper, 1964; Free, 1966), the amount depending, of course, on the proportion of plants that have grown from self-fertilized and cross-fertilized seed.

We have now attempted to discover to what extent yield of commercial crops is limited by insufficient pollination.

\section{METHOD}

Observations were made in 1970 and 1971 on 30 and 7 crops, respectively, of spring-sown field beans. Field size varied from 2 to 40 ha in 1970 (mean $11 \mathrm{ha}$ ) and from 4 to $16 \mathrm{ha}$ in 1971 (mean 9 ha).

During flowering in 1970,30 plants near the centre of each field and 30 plants $10 \mathrm{~m}$ from the edge of the field were labelled and metal plant rings put below the lowest node and above the highest node that had two or more flowers open. The plants were allocated in order into three treatments in which all the open flowers (about 12) between the plant rings were either $(a)$ self-pollinated by $\mathrm{de}$. pressing the keel to push the pollen plug on to the stigma, or $(b)$ cross-pollinated by depressing the keel and brushing the exposed stigma with pollen from three or more flowers of other plants, or (c) not pollinated by hand and left to be pollinated naturally. Just before the crop was harvested the entire plants were removed. From the treated section of each plant, the lower part that flowered before the treated section (pre-treatment section) and the upper part that flowered after the treated section (post-treatment section) the pods and seeds were counted and the seeds were weighed.

The method used in 1971 was similar except that each of the 30 plants used in the centres and edges of the fields received all three treatments. The open flowers on three adjacent flowering nodes on each plant were $(a)$ self-pollinated by hand, $(b)$ crosspollinated by hand, or $(c)$ not pollinated by hand, respectively, equal numbers of each treatment 
Table 1. Pod and seed production in the centre and edge of fields

\begin{tabular}{|c|c|c|c|c|}
\hline & \multicolumn{4}{|c|}{ Location of plants in field } \\
\hline & \multicolumn{2}{|c|}{1970} & \multicolumn{2}{|c|}{1971} \\
\hline & Edge & Centre & Edge & Centre \\
\hline Mean wt. (g) per seed & $0 \cdot 30$ & $0 \cdot 30$ & 0.36 & 0.32 \\
\hline Mean no. seeds per pod & $2 \cdot 47$ & $2 \cdot 39$ & $3 \cdot 30$ & $3 \cdot 23$ \\
\hline Mean no. pods per node & $1 \cdot 62$ & $1 \cdot 68$ & $1 \cdot 90$ & $1 \cdot 84$ \\
\hline Mean no. seeds per plant & $18 \cdot 30$ & $18 \cdot 59$ & $32 \cdot 82$ & 33.48 \\
\hline
\end{tabular}

Table 2. Number of crops in which the seed production of flowers self-pollinated and cross-pollinated by hand exceeded that of control flowers

\begin{tabular}{|c|c|c|c|c|c|c|}
\hline & \multicolumn{2}{|c|}{1970 (30 crops) } & \multicolumn{2}{|c|}{1971 (7 crops) } & \multicolumn{2}{|c|}{1970 and 1971 (37 crops) } \\
\hline & $\begin{array}{l}\text { Self- } \\
\text { pollinated } \\
\text { flowers }\end{array}$ & $\begin{array}{l}\text { Cross- } \\
\text { pollinated } \\
\text { flowers }\end{array}$ & $\begin{array}{l}\text { Self- } \\
\text { pollinated } \\
\text { flowers }\end{array}$ & $\begin{array}{l}\text { Cross- } \\
\text { pollinated } \\
\text { flowers }\end{array}$ & $\begin{array}{c}\text { Self- } \\
\text { pollinated } \\
\text { flowers }\end{array}$ & $\begin{array}{l}\text { Cross- } \\
\text { pollinated } \\
\text { flowers }\end{array}$ \\
\hline Edge of field & 17 & 20 & 4 & 6 & 21 & $26^{*}$ \\
\hline Centre of field & 19 & 19 & $7 * *$ & $7 * *$ & $26^{*}$ & $26 *$ \\
\hline Edge and centre of field & 36 & $39 * *$ & $11^{*}$ & $13^{* *}$ & $47^{*}$ & $52 * * *$ \\
\hline Mean of edge and centre of field & 19 & 20 & 6 & $7 * *$ & $25^{*}$ & $27 * *$ \\
\hline
\end{tabular}

being allocated to nodes in each of the relative positions.

\section{RESULTS}

The average yield of plants at the centres and edges of the fields were similar (Table 1) and such differences as occurred were not consistent. Thus plants near the edges of 15 of 30 fields in 1970 and 3 of 7 fields in 1971, had more seeds per plant than those near the centres of the fields. However, field size appeared to influence the result as there were more seeds per plant at the edges than the centres of 9 of 10 fields more than 12 ha in size compared with 10 of 27 fields less than 12 ha in size $(P<0.01)$. There were no other significant differences asso. ciated with field size.

In most crops hand-pollinated flowers set more seed than control flowers (Table 2). Any advantage of cross-pollination over self-pollination was not great. The mean amounts of seed produced by the different treatments is given in Table 3. Much of the increase in set of the hand-pollinated sections was maintained in the yield of the plant as a whole, and, in 1971, plants with self- and cross-pollinated flowers produced more seed than control plants in 19 and 20 fields, respectively.

In general, flowers on the part of the plant that was hand-pollinated, and earlier flowers lower on the stem, produced more seeds per pod, more pods per node and larger seeds, than flowers that were produced later (Tables 4 and 5 ).

\section{DISCUSSION AND CONCLUSIONS}

Because hand-pollination increased the flower set of many crops it is apparent that they were being inadequately pollinated. This may be overcome by importing colonies of honeybees or growing the crops in areas in which bumblebees are abundant. Bond \& Pope (1974) found that the amount of crossing in field bean crops was associated with the suitability of the site for bumblebees. However, as pointed out by the Ministry of Agriculture, Fisheries \& Food (1970) the number of bumblebees and other wild pollinators is unlikely to be adequate for large fields.

Bond \& Pope (1974) also found that in general more crossing occurs in small than in large fields, and a higher proportion of cross-fertilized seed survives at their centres than at their edges due to mortality of self-fertilized embryos; they suggested that the critical size of field requiring extra bees is between 12 and 32 ha. The greater seed set near the edges than the centres of our large fields (over 





Table 4. Number of crops in which the seed and pod production of the pre-treatment flowers and the treated flowers (hand-pollinated) exceeds that of the post-treatment flowers

\begin{tabular}{|c|c|c|c|c|c|c|}
\hline & \multicolumn{2}{|c|}{1970 (30 crops) } & \multicolumn{2}{|c|}{1971 (7 crops) } & \multicolumn{2}{|c|}{1970 and 1971 (37 crops) } \\
\hline & $\begin{array}{l}\text { Pre-treatment } \\
\text { flowers }\end{array}$ & $\begin{array}{l}\text { Treated } \\
\text { flowers }\end{array}$ & $\begin{array}{c}\text { Pre-treatment } \\
\text { flowers }\end{array}$ & $\begin{array}{l}\text { Treated } \\
\text { flowers }\end{array}$ & $\begin{array}{c}\text { Pre-treatment } \\
\text { flowers }\end{array}$ & $\begin{array}{l}\text { Treated } \\
\text { flowers }\end{array}$ \\
\hline \multicolumn{7}{|l|}{ Wt. (g) per seed } \\
\hline Edge of field & $23^{* *}$ & 17 & 6 & 6 & $29 * * *$ & 23 \\
\hline Centre of field & $24^{* *}$ & 20 & 6 & 5 & $30^{* * *}$ & $25^{*}$ \\
\hline Mean of edge and centre of field & $23^{* *}$ & 20 & 6 & 6 & $29 * * *$ & $26^{*}$ \\
\hline \multicolumn{7}{|l|}{ No. of seeds per pod } \\
\hline Edge of field & $24^{* *}$ & $26 * * *$ & $7 * *$ & 6 & $31 * * *$ & $32 * * *$ \\
\hline Centre of field & $22^{*}$ & $27^{* * *}$ & 5 & 6 & $27 * *$ & $33^{* * *}$ \\
\hline Mean of edge and centre of field & $24^{* *}$ & $27^{* * *}$ & 5 & $7 * *$ & $29 * * *$ & $34^{* * *}$ \\
\hline \multicolumn{7}{|l|}{ No. of pods per node } \\
\hline Edge of field & $25^{* * *}$ & $30 * * *$ & 6 & $7 * *$ & $31^{* * *}$ & $37^{* * *}$ \\
\hline Centre of field & $25^{* * *}$ & $30^{* * *}$ & 6 & $7 * *$ & $31 * * *$ & $37^{* * *}$ \\
\hline Mean of edge and centre of field & $27^{* * *}$ & $30 * * *$ & $7 * *$ & $7 * *$ & $33^{* * *}$ & $37 * * *$ \\
\hline
\end{tabular}

Table 5. Seed and pod production by early, treated and late flowers

\begin{tabular}{|c|c|c|c|c|c|c|}
\hline & \multicolumn{3}{|c|}{1970} & \multicolumn{3}{|c|}{1971} \\
\hline & $\begin{array}{l}\text { Pre-treatment } \\
\text { flowers (early) }\end{array}$ & $\begin{array}{l}\text { Treated } \\
\text { flowers }\end{array}$ & $\begin{array}{r}\text { Post-treatment } \\
\text { flowers (late) }\end{array}$ & $\begin{array}{l}\text { Pre-treatment } \\
\text { flowers (early) }\end{array}$ & $\begin{array}{l}\text { Treated } \\
\text { flowers }\end{array}$ & $\begin{array}{r}\text { Post-treatment } \\
\text { flowers (late) }\end{array}$ \\
\hline \multicolumn{7}{|c|}{ - } \\
\hline Edge of field & $7 \cdot 18$ & 8.79 & 2.02 & $5 \cdot 28$ & $19 \cdot 56$ & $\mathbf{7 . 9 6}$ \\
\hline Centre of field & $7 \cdot 14$ & $8 \cdot 64$ & $2 \cdot 40$ & $3 \cdot 75$ & $19 \cdot 30$ & $10 \cdot 74$ \\
\hline Edge and centre of field & $7 \cdot 16$ & $8 \cdot 71$ & $2 \cdot 21$ & $4 \cdot 51$ & $19 \cdot 43$ & $9 \cdot 35$ \\
\hline \multicolumn{7}{|l|}{ Mean wt. $(\mathrm{g})$ per seed } \\
\hline Edge of field & 0.35 & 0.32 & 0.30 & 0.36 & 0.36 & $0 \cdot 34$ \\
\hline Centre of field & 0.32 & $0 \cdot 30$ & 0.28 & 0.35 & 0.33 & 0.29 \\
\hline Edge and centre of field & 0.34 & $0 \cdot 31$ & $0 \cdot 29$ & 0.35 & 0.34 & 0.31 \\
\hline \multicolumn{7}{|l|}{ Mean no. of seeds per pod } \\
\hline Edge of field & $2 \cdot 62$ & $2 \cdot 52$ & $2 \cdot 12$ & $3 \cdot 38$ & $3 \cdot 31$ & 3.08 \\
\hline Centre of field & $2 \cdot 52$ & $2 \cdot 55$ & $2 \cdot 04$ & $3 \cdot 23$ & $3 \cdot 52$ & 3.03 \\
\hline Edge and centre of field & $2 \cdot 57$ & $2 \cdot 54$ & $2 \cdot 08$ & $\mathbf{3 \cdot 3 0}$ & $3 \cdot 41$ & 3.05 \\
\hline \multicolumn{7}{|l|}{ Mean no. of pods per node } \\
\hline Edge of field & 1.83 & 1.92 & $1 \cdot 13$ & $2 \cdot 04$ & 1.98 & $1 \cdot 55$ \\
\hline Centre of field & 1.92 & 1.85 & $1 \cdot 21$ & $1 \cdot 70$ & 1.95 & 1.66 \\
\hline Edge and centre of field & $1 \cdot 87$ & 1.89 & $1 \cdot 17$ & 1.86 & 1.96 & 1.60 \\
\hline
\end{tabular}

12 ha) probably reflects the greater abundance of pollinators near the edges, and emphasizes the need for more pollinating insects in such circumstances.
We are grateful to Dr D. A. Bond of the Plant Breeding Institute, Cambridge, for helpful discussion and encouragement.

\section{REFERENCES}

Bond, D. A. \& Pope, M. (1974). Factors affecting the proportions of cross-bred and self-bred seed obtained from field bean (Vicia faba L.) crops. Journal of Agricultural Science, Cambridge 83, 343-51.

COOPER, B. A. (1964). Pollination of field beans. British Bee Journal 92, 92-3, 102-3.
Drayner, Jean M. (1959). Self- and cross-fertility in field beans (Vicia faba L.). Journal of Agricultural Science, Cambridge 53, 387-402.

FrEe, J. B. (1966). The pollination requirements of broad beans and field beans (Vicia faba L.). Journal of Agricultural Science, Cambridge 66, 395-7. 
FyFe, J. L. (1954). Plant breeding studies in leguminous forage crops. II. Further observations on natural cross-breeding in winter beans. Journal of Agricultural Science, Cambridge 45, 141-7.

Fyre, J. L. \& BAmex, N. T. J. (1951). Plant breeding studies in leguminous forage crops. I. Natural crossing in winter beans. Journal of Agricultural Science, Cambridge 41, 371-8.

HuA, H. (1943). Natural crossing in Vicia faba. Chinese Journal of Scientific Agriculture 1, 63-5.

Ministry of Aariculture, Fisheries \& Food (1970). Field Beans. Short term leaflet 60, pp. 18.

RIEDec, I. B. M. \& Wort, D. A. (1960). The pollination requirement of the field bean (Vicia faba). Annals of Applied Biology 48, 121-4.
Rowlands, D. G. (1958). The nature of the breeding system in the field bean ( $V . f a b a \mathrm{~L}$.) and its relationship to breeding for yield. Heredity 12, 113-26.

Scriven, W. A., Cooper, B. A. \& Allen, H. (1961). Pollination of field beans. Outlook on Agriculture 3, 69-75.

SrRKs, M. J. (1923). Die Verschiebung genotypischer Verhältniszahlen innerhalb Polulationen laut Mathematischer Berechnung und Experimenteller Prüfung. Mededeelingen van de Landbouwhoogeschool, Wageningen 26.

WatTs, F. H. \& Marshall, P. R. (1961). Pollination of field beans. Yield response due to bees. Report on field experiments and observation studies. East Midland Region. pp. 76-9. 